\title{
Association between the SLC6A3 A1343G polymorphism and schizophrenia
}

\author{
Quirino Cordeiro', Jacqueline Siqueira-Roberto², Homero Vallada ${ }^{3}$
}

\begin{abstract}
Epidemiological studies have demonstrated that the genetic component is an important risk factor for the development of schizophrenia. The genes that codify the different compounds of the dopaminergic system have created interest for molecular investigations in patients with schizophrenia because the antipsychotic drugs, especially those of first generation, act on this cerebral system. Thus the aim of the present study was to investigate the possible association between a new single nucleotide polymorphism (rs6347) located in exon 9 of the protein transporter (SLC6A3) and schizophrenia. The distribution of the alleles and genotypes of the studied polymorphism was investigated in a sample of 235 patients and 834 controls matched by gender and age. There were statistical differences in the allelic $\left(\chi^{2}=5.97,1 d\right.$.f., $\left.p=0.01, O R=1.33-1.05<O R<1.69\right)$ and genotypic $\left(\chi^{2}=6.56,2 d . f ., p=0.03\right)$ distributions between patients and controls. Thus the SLC6A3 A1343G polymorphism was associated to the SCZ phenotype in the investigated sample.
\end{abstract}

Key words: association study, dopamine, dopamine transporter, genetics, psychosis.

\section{Associação entre o polimorfismo A1343G do SLC6A3 e esquizofrenia}

\section{RESUMO}

Estudos epidemiológicos têm demonstrado que o componente genético é um importante fator de risco para a esquizofrenia. Os genes que codificam os diferentes componentes do sistema dopaminérgico passaram a despertar interesse para estudos moleculares em pacientes com esquizofrenia, pois os antipsicóticos, em especial os de primeira geração, exercem sua ação nesse sistema. Assim, o objetivo do presente estudo foi investigar a associação entre um novo polimorfismo de nucleotídeo único (rs6347) localizado no exon 9 do gene do transportador de dopamina (SLC6A3) e esquizofrenia. Um total de 235 pacientes e 834 controles pareados para sexo e idade foi selecionado para a investigação da distribuição dos alelos e genótipos do polimorfismo investigado entre os grupos de pacientes e controles. Houve diferenças estatisticamente significantes nas distribuições alélicas $\left(\chi^{2}=5,97,1\right.$ d.f., $\left.p=0,01, O R=1,33-1,05<O R<1,69\right)$ e genotípicas $\left(\chi^{2}=6,56,2\right.$ d.f., $p=0,03)$ entre pacientes e controles. Assim, o polimorfismo SLC6A3 A1343G mostrou associação com esquizofrenia na amostra estudada.

Palavras-chave: estudo de associação, dopamina, transportador de dopamina, genética, psicose.

\section{Correspondence \\ Quirino Cordeiro \\ Rua Cônego Eugênio Leite 594 / 174 05414-000 São Paulo SP - Brasil \\ E-mail: qcordeiro@yahoo.com}

Received 14 December 2009

Received in final form 8 March 2010

Accepted 17 March 2010
Schizophrenia (SCZ) is a psychiatric disorder characterized by psychotic symptoms, alterations of thought, affect, volition and behavior and affects some $1 \%$ of the general population. Genetic epidemiological investigations have suggested that there is an important participation of a genetic component on the etiology of SCZ and heritability estimates as high as $80 \%$ have been reported ${ }^{1}$. The mode of inheritance is complex showing a polygenic-environmental interaction. The role of a sin- 
gle relevant gene must be small, thus association studies, involving case-control approaches, have been performed to evaluate the allelic variations at specific candidate genes which may be related to the etiopathology of the disorder².

Some of the most investigated genes in studies of vulnerability to $\mathrm{SCZ}$ are those that code for proteins of the dopaminergic system because the evidences of the role of central dopamine pathways in the pathophysiology of the disorder ${ }^{3-5}$. Stimulant drugs, that block reuptake of dopamine or facilitate its release on neuronal synapses, may induce psychotic symptoms ${ }^{6}$. L-DOPA has also been related to psychotic symptoms through variable release of dopamine into the synapse ${ }^{6}$. Some antipsychotic drugs correlate their efficacy with their action at dopaminergic receptors ${ }^{7}$. Therefore, genes involved in the dopaminergic system are potential targets for genetic association investigations with SCZ.

Polymorphisms in dopamine receptors genes have been widely investigated as risk factors for SCZ development, however the results have been inconclusive $e^{3-5}$. Another possible candidate for such investigations is the dopamine transporter gene (SLC6A3 or DAT1). The dopamine transporter plays an important role in the regulation of dopamine levels and neurotransmission by mediating the active re-uptake of synaptic dopamine back into the neurons ${ }^{8}$. Two post-mortem studies on SLC6A3 binding and SCZ showed decreased striatal SLC6A3 density in chronic $\mathrm{SCZ}^{9,10}$. A recent study using positron emission tomography found lower SLC6A3 density in sites in the basal ganglia, particularly in the middle third of putamen, in chronic SCZ patients than controls. This may suggest a decreased expression of SLC6A3 in a subset of chronic SCZ patients ${ }^{11}$.

The SLC6A3 was cloned and mapped to human chromosome $5(5 \mathrm{p} 15.3)^{12}$. A new single nucleotide polymorphism (SNP) was identified in exon 9 of the SLC6A3 $(\text { rs6347 })^{13}$. There is an A1343G substitution, however this is a synonymous polymorphism and there is no aminoacide change (Ser/Ser). As far as we know the present study is the first one investigating the SLC6A3 A1343G polymorphism as a risk factor for SCZ development.

\section{METHOD}

\section{Sample}

Our sample was consisted of 235 (male $=152: 64.68 \%$; female $=83$ : $35.32 \%$ ) Brazilian SCZ patients, and recruited at the Institute of Psychiatry, Hospital das Clínicas, University of São Paulo Medical School. The diagnosis of SCZ was made according to the Diagnostic and Statistical Manual of Mental Disorders - Fourth Edition (DSM-IV) ${ }^{14}$ criteria, based on a clinical interview conducted by a psychiatrist. A total of 834 (male $=520: 62.35 \%$; female $=314$ :
37.65\%) healthy control subjects were selected from unrelated subjects admitted to the Blood Donation Center of the Fundação Pró-Sangue of the University of São Paulo Medical School.

All patients and control subjects provided written informed consent for taking blood samples. Ethical approval for the study was obtained from the Ethics Committee at the Hospital das Clínicas, University of São Paulo Medical School (CAPPesq).

\section{DNA extraction}

Blood samples $(10 \mathrm{~mL})$ were collected from all participants of the study, and DNA was extracted from leukocytes using the "salting out" protocol ${ }^{15}$.

\section{Genotyping}

Genotyping of the investigated polymorphism for this study was performed blind to the clinical status of the individuals according to Greenwood et al. ${ }^{13}$ and Guindalini et al. ${ }^{16}$.

To avoid errors, genotyping was read by two independently trained research technicians. When a disagreement arose the genotyping was repeated. In addiction, random re-genotyping was repeated in $20 \%$ of the sample.

\section{Statistical analysis}

The statistical power of the sample was evaluated using the CaTS Program (Center for Statistical Genetics The University of Michigan) (http://www.sph.umich.edu/ csg/abecasis/CaTS/index.html).

A test for deviations from the Hardy-Weinberg equilibrium was performed using the HWE program ${ }^{17}$.

Allelic and genotypic distributions of the SLC6A3 A1343G polymorphism were compared between 235 patients and 834 healthy controls. Chi-square test, used to investigate possible association between genotypes and alleles with SCZ, was performed by the EpiInfo version 6.0. Chi-square test was also used to investigate difference between gender distribution between the groups of patients and controls. Differences of age between the investigated groups were analyzed using student's t-test.

For all statistic tests the level of significance adopted was $\alpha<0.05$ or $5 \%$.

\section{RESULTS}

The power of the sample, based on 235 patients and 834 controls, disorder prevalence of $1 \%$, average allelic frequency around 20\%, multiplicative model with the genotype relative risk $=1.5$ and significance level of 0.05 , was $97 \%$.

There were no significant deviations from HardyWeinberg equilibrium in the patients $(\mathrm{p}=0.28)$ and controls $(\mathrm{p}=0.69)$ samples for the SLC6A3 A1343G polymorphism. 
Table. Distributions of the SLC6A3 A1343G alleles and genotypes frequencies in SCZ patients and controls samples.

\begin{tabular}{lccccc}
\hline Polymorphism & Cases (\%) & Controls (\%) & $\chi^{2}$ & d.f. & p \\
\hline Genotypes & & & & \\
A/A & $132(56.17)$ & $393(47.12)$ & & & \\
A/G & $84(35.74)$ & $356(42.69)$ & 6.56 & 2 & 0.03 \\
G/G & $19(8.09)$ & $85(10.19)$ & & & \\
Total & $235(100)$ & $834(100)$ & & & \\
Alleles & & & & \\
A & $348(74.04)$ & $1142(68.47)$ & & & 0.01 \\
G & $122(25.96)$ & $526(31.53)$ & 5.97 & 1 & \\
Total & $470(100)$ & $1668(100)$ & & & \\
\hline$\chi^{2}$ : Chi-square test; DF: degrees of freedon; P: probability. & & &
\end{tabular}

For patients, mean age was $28.3 \pm 6.9$ years (19-64) and median age was 26.4 years. For controls, mean age was $31.2 \pm 8.3$ years (18-79) and median age was 29.1 years There was no statistical difference related to age between the groups of patients and controls $(\mathrm{p}=0.21)$. Statistical analysis did not evidence difference related to gender distribution between the groups investigated as well $\left(\chi^{2}=0.43 ; \mathrm{p}=0.51\right)$.

There were statistical differences in the allelic $\left(\chi^{2}=5.97\right.$, 1 d.f., $\mathrm{p}=0.01, \mathrm{OR}=1.33-1.05<\mathrm{OR}<1.69)$ and genotypic $\left(\chi^{2}=6.56,2\right.$ d.f., $\left.\mathrm{p}=0.03\right)$ distributions between patients and controls (Table).

\section{DISCUSSION}

Findings of post-mortem and neuroimaging studies have suggested that SLC6A3 may play a role in the pathophysiology of $\mathrm{SCZ}^{9-11}$. The evidences of involvement of the dopaminergic system in the pathophisiology of SCZ have collaborated to the investigation of genetic polymorphisms of this cerebral pathway on such disorder. There are previous studies that investigated the role of different SLC6A3 polymorphisms as risk factors for SCZ development ${ }^{4}$ however to our knowledge this is the first investigation to perform an association study between the SLC6A3 A1343G polymorphism and such disorder. This is a synonymous polymorphism and it does not promote a change of amino acids $(\mathrm{Ser} / \mathrm{Ser})^{13}$. However the investigation of synonymous polymorphisms is important because they may in linkage disequilibrium with another polymorphism on SLC6A3 which is a gene of interest for SCZ research. Moreover recent study has demonstrated that synonymous polymorphisms may alter gene translation. Duan et al. found that some synonymous mutations in the human DRD2 gene have functional effects, alter the predicted mRNA folding, led to a decrease in mRNA stability and translation, and dramatically change dopamine-induced up-regulation of DRD2 ex- pression, indicating that synonymous variations can have effects on pathophysiological aspects of psychiatric disorders such as $\mathrm{SCZ}^{18}$.

As the investigated polymorphism may be in linkage disequilibrium with another polymorphism on SLC6A3 which could influence the risk for the SCZ, it could be premature to assess the validity of the association found in the present work. Moreover in populations of highly admixed ethnicity like the Brazilian one, we may face problems about ethnical stratification ${ }^{19-21}$. Physical phenotype in Brazil is not an adequate predictor of genomic ancestry what difficult the ethnical matching in case-controls studies ${ }^{22}$. However the fact that the present sample (patients and controls) is in Hardy-Weinberg equilibrium indicates that our sample may not have important problems regarding population stratification ${ }^{23}$. It is also important to note that ethnical matching conducted using genetic markers was performed in part of our sample in a case-control study with cocaine dependence and the results showed that, despite the ethnic admixture in Brazil, the ethnic stratification was not a bias in that case ${ }^{24}$.

In conclusion, the results of the present investigation provide evidence for the association between the polymorphism SLC6A3 A1343G polymorphism and SCZ in our Brazilian sample. However to confirm the association of this polymorphism with SCZ further studies must be conducted focusing on ethnical aspects. It is always important to consider the possibility that the investigated polymorphism is in linkage disequilibrium with nonidentified genes that are in fact those contributing to the pathogenesis of SCZ or even with other polymorphisms within the SLC6A3 therefore more comprehensive polymorphisms coverage within the SLC6A3 is warranted. The genetic association found in the present work could be clarified by the analysis of larger case-control studies, additional family-based studies, and especially linkage disequilibrium mapping of SLC6A3, which should be 
considered an important gene given its potential important influence on the risk for SCZ development.

\section{REFERENCES}

1. McGuffin P, Owen MJ, Farmer AE. The genetic basis of schizophrenia. Lancet 1995;346:678-682.

2. Norton N, Williams HJ, Owen MJ. An update on the genetics of schizophrenia. Curr Opin Psychiatry 2006;19:158-164.

3. Cordeiro Q Jr, Junqueira R, Vallada H. Study of association between the ser9-gly of the D3 dopaminergic receptor and schizophrenia. Arq Neuropsiquiatr 2001;59:219-222.

4. Cordeiro Q, Talkowski M, Wood J, Ikenaga E, Vallada H. Lack of association between VNTR polymorphism of dopamine transporter gene (SLC6A3) and schizophrenia in a Brazilian sample. Arq Neuropsiquiatr 2004;62:973-976.

5. Cordeiro Q, Siqueira-Roberto J, Zung S, Vallada H. Association between the DRD2-141C insertion/deletion polymorphism and schizophrenia. Arq Neuropsiquiatr 2009;67:191-194.

6. Bell D. Comparison of amphetamine psychosis and schizophrenia. Br J Psychiatry 1965;111:701-707.

7. Seeman P. Atypical antipsychotics: mechanism of action. Can J Psychiatry 2002; 47:27-38.

8. Jaber M, Jones S, Giros B, Caron MG. The dopamine transporter: a crucial component regulating dopamine transmission. Mov Disord 1997;12:629-633.

9. Laakso A, Bergman J, Haaparanta M, et al. Decreased striatal dopamine transporter binding in vivo in chronic schizophrenia. Schizophr Res 2001;52: 115-120.

10. Knable MB, Hyde TM, Herman MM, Carter JM, Bigelow L, Kleinman JE. Quantitative autoradiography of dopamine-D1 receptors, D2 receptors, and dopamine uptake sites in postmortem striatal specimens from schizophrenic patients. Biol Psychiatry 1994;36:827-835.

11. Chinaglia G, Alvarez FJ, Probst A, Palacios JM. Mesostriatal and mesolimbic dopamine uptake binding sites are reduced in Parkinson's disease and progressive supranuclear palsy: a quantitative autoradiographic study using $[3 \mathrm{H}]$ mazindol. Neuroscience 1992:49:317-327.
12. Giros B, Mestikawy S, Godinot N, et al. Cloning, pharmacological characterization, and chromosome assignment of the human dopamine transporter. Mol Pharmacol 1992;42:383-390.

13. Greenwood TA, Alexander M, Keck PE, et al. Segmental linkage disequilibrium within the dopamine transporter gene. Mol Psychiatry 2002;7:165-173.

14. American Psychiatric Association. Diagnostic and statistical manual of mental disorders. $4^{\text {th }}$ Ed. Washington, DC: American Psychiatric Association, 1994.

15. Miller SA, Dykes DD, Polesky, HF. A single salting out procedure for extracting DNA from human nucleated cells. Nucleic Acids Res 1988;16:1215.

16. Guindalini C, Howard M, Haddley K, et al. A dopamine transporter gene functional variant associated with cocaine abuse in a Brazilian sample. Proc Natl Acad Sci U S A 2006;103:4552-4557.

17. Ott J. Methods of analysis and resources available for genetic trait mapping. J Hered 1999;90:68-70.

18. Duan J, Wainwright MS, Comeron JM, et al. Synonymous mutations in the human dopamine receptor D2 (DRD2) affect mRNA stability and synthesis of the receptor. Hum Mol Genet 2003;12:205-216.

19. Silva MA, Cordeiro Q, Miracca EC, Guindalini C, Vallada H. Distribution of alleles of the VNTR polymorphism in the $3^{\prime}$-untranslated region of the DAT1 gene (SLC6A3) in São Paulo/Brazil and its importance to genetic studies of neuropsychiatric disorders in ethically admixed populations. Rev Med Chil 2005;133:1392-1393.

20. Cordeiro Q, Souza BR, Correa H, et al. A review of psychiatric genetics research in the Brazilian population. Rev Bras Psiquiatr 2009;31;154-162.

21. Cordeiro Q, Souza BR, Correa $H$, et al. Population stratification in European South-American subjects and its importance to psychiatric genetics research in Brazil. Rev Bras Psiquiatr 2010;32:92-94.

22. Parra FC, Amado RC, Lambertucci JR, Rocha J, Antunes CM, Pena SD. Color and genomic ancestry in Brazilians. Proc Natl Acad Sci USA 2003;100: 177-182.

23. Weiss ST, Silverman EK, Palmer LJ. Editorial: case-control association studies in pharmacogenetics. Pharmacogenomics J 2001;1:157-158.

24. Guindalini C, O'Gara C, Laranjeira R, et al. A GSTP1 functional variant associated with cocaine dependence in a Brazilian population. Pharmacogenet Genomics 2005;15:891-893. 